\title{
ИК-СПЕКТРОМЕТРИЯ ДЛЯ КОЛИЧЕСТВЕННОГО КОНТРОЛЯ ПРОЦЕССА СИНТЕЗА ГЛИФОСАТА
}

Ющенко Д.Ю., Т.Б. Хлебникова Т.Б, Пай З.П.

ФГБУН ФИЦ Институт катализа им. Г. К. Борескова СО РАН, Новосибирск, Россия

$$
\text { dyy@catalysis.ru }
$$

DOI: 10.26902/ASFE-11_88

Действующем веществом наиболее распространённых средств защиты растений является $N$-(фосфонометил)-глицин, также известный как глифосат (2). Одним из промышленных способов его получения является каталитическое окисление $N$ (фосфонометил)-иминодиуксусной кислоты (ФИДУК, 1) пероксидом водорода [1], в котором важную роль играет контроль качества готового продукта. В настоящее время все описанные способы количественного анализа глифосата и/или ФИДУК, основаны на хромофотографических методах (ГХ, ВЭЖХ, ТСХ), предполагающих разделение компонентов с последующим их количественным анализом $[2,3]$ и требуют использования сложного оборудования и дорогостоящих реагентов. Поэтому разработка сравнительно простых способов анализа этих соединений остается актуальной. В этой связи использование метода ИК-спектрометрии [4] для решения задач количественного определения глифосата и ФИДУК при совместном присутствии является востребованным.

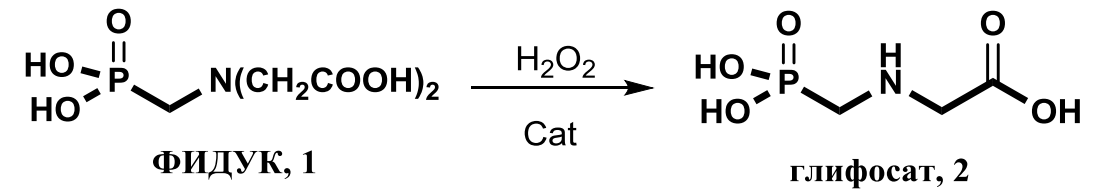

Рис. Синтез глифосата из ФИДУК.

В ходе работы были выбраны индивидуальные, неперекрывающиеся полосы

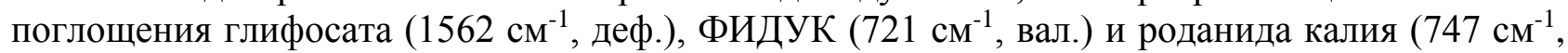
вал.), используемого в качестве внутреннего стандарта. Количественное определение (1) и/или (2) выполняли, основываясь на соотношении оптических плотностей, анализируемого компонента к роданиду калия. Определено соотношение [Глифосат или ФИДУК]/[роданид калия], обеспечивающее воспроизводимость анализа. Установлены пределы (мг) обнаружения: глифосат - 11.9; ФИДУК - 13.2. Оценка точности и воспроизводимости метода выполнена по принципу «введено-найдено», а апробация проведена при анализе реакционных смесей, получающихся при окислении ФИДУК пероксидом водорода [1]. Предлагаемый способ позволяет решать задачу количественного анализа глифосата и ФИДУК, обеспечивая получение воспроизводимых и удовлетворительных результатов.

\section{Список литературы}

1. З.П. Пай, Д.Ю. Ющенко, Т.Б. Хлебникова, В.Н. Пармон Патент РФ. №2618629 // Б. и. 2017. №13.

2. Зеленкова Н.Ф., Винокурова Н.Г.// Журн. аналит. химии. 2008. Т. 65. № 9. С. 958. (Zelenkova N.F., Vinokurova N.G.// J. Analyt. Chem. 2008. V. 63. № 9. P. 871.).

3. Roy D.N., Konar S.K.// J. Agric. Food Chem. 1989. V. 37. № 2. P. 441.

4. Ющенко Д.Ю., Хлебникова Т.Б., Малышева Л.В., Баранова С.С., Пай 3.П.// Журн. аналит. химии. 2013. Т. 68. № 11. C.1075. (Yushchenko D. Yu., Malysheva L. V., Baranova S. S., Khlebnikova T. B., Pai Z. P.// J. Analyt. Chem. 2013. V. 68. № 11. P. 961.).

Работа выполнена в рамках государственного задания ИК СО РАН проект 0239-2021-0005 и при финансовой поддержке РФФИ (проект № 19-03-00202a). 